\title{
Droga doskonalenia chrześcijańskiego w nauczaniu Grzegorza Wielkiego
}

Od początku istnienia Kościół prowadzi wiernych drogą duchowego doskonalenia, czyli drogą dążenia do duchowej łączności z Bogiem. Bez wątpienia, prawdziwymi mistrzami w ukazywaniu tej drogi w pierwszych wiekach chrześcijaństwa byli Ojcowie Kościoła, których nauka nadal pozostaje aktualna ${ }^{1}$, a doświadczenia i poglądy w tej kwestii należą do skarbca współczesnej teologii duchowości. Nauczycielem duchowości, do którego myśli odwołujemy się w niniejszej prezentacji, jest papież Grzegorz Wielki (540-604), człowiek o nieprzeciętnej osobowości, którego działalność stanowi niejako klamrę spinającą refleksje i doświadczenia okresu patrystycznego ${ }^{2}$.

Grzegorz Wielki naucza, że człowiekowi stworzonemu na obraz Boży i przeznaczonemu do Jego kontemplowania zostało w naturę wpisane pragnienie Boga ${ }^{3}$. Człowiek jednak musi odczytać w sobie to pragnienie, pobudzić je i nieustannie rozwijać, aby ostatecznie urzeczywistniło się ono w duchowym złączeniu z Absolutem. Łączność z Bogiem zakłada posiadanie cnót, dlatego aby uzyskać ją, konieczne jest nabywanie cnót i doskonalenie

${ }^{1}$ Por. Instrukcja Kongregacji ds. Wychowania Katolickiego, O studium Ojców Kościoła $w$ formacji kapłańskiej, „Vox Patrum” 10 (1990) t. 18, s. 20; Jan Paweł II, List apostolski na 1600-lecie śmierci świętego Bazylego Patres Ecclesiae, „Vox Patrum” 2 (1980) t. 3, s. 247-248; L. Małunowiczówna, Aktualność Ojców Kościoła, [w:] Z zagadnień kultury chrześcijańskiej, red. K. Wojtyła, Lublin 1973, s. 137-146; M. Pellegrino, Czy Ojcowie Kościoła mają coś do powiedzenia wspótczesnemu człowiekowi?, „Vox Patrum” 9 (1989) t. 16, s. 111-120.

${ }^{2}$ Por. B. Częsz, Święty Grzegorz Wielki - wzór człowieka i pasterza, „Teologia Patrystyczna” 2 (2005), s. 8-9. Na temat aktualności myśli Grzegorza Wielkiego por. J. Leclercq, Actualité de Grégoire le Grand, [w:] Grégoire le Grand. Chantilly Centre culturel Les Fontaines 15-19 septembre 1982, actes publiés par J. Fontaine, R. Gillet, S. Pellistrandi, Paris 1986, s. 681-684.

${ }^{3}$ Por. Gregorius Magnus, Moralia in Iob IX, 49, 75; IX, 33, 50; VIII, 18, 34; VII, 2, 2; XXXII, 10, 12; zob. S. Rosik, Dążenie do nieba jako nakaz historiozbawczy w doktrynie Grzegorza Wielkiego, „Roczniki Teologiczno-Kanoniczne” 22 (1975) 3, s. 33-43; tenże, Finalizm życia chrześcijańskiego w świetle twórczości papieża Grzegorza Wielkiego, Lublin 1980, s. 199-205; M. M. Casey, Spiritual Desire in the Gospel Homilies of Saint Gregory the Great, „Cistercian Studies" 16 (1981) 4, s. 299-300. 
się w nich ${ }^{4}$. W zrealizowaniu tego celu pomocne są człowiekowi różne środki, dzięki którym może dokonać się proces duchowego doskonalenia chrześcijanina. Przedstawieniu tych środków zostaje poświęcony niniejszy artykuł.

W pierwszej części artykułu zostanie przedstawiona rola Bożej łaski w procesie nabywania i utrwalania cnót. W części drugiej zostaną omówione środki, przez których praktykowanie człowiek współpracuje z darem Bożej łaski, podporządkowując Bogu swoją wolną wolę.

\section{Łaska Boża}

W przekonaniu Grzegorza Wielkiego człowiek o własnych siłach nie może odczytać i pobudzić wpisanego w swoją naturę pragnienia Boga. Po upadku w grzech pierworodny duchowe zdolności ludzkiej natury poważnie osłabły i bez pomocy Bożej osoba ludzka nie może osiągnąć duchowej łączności z Bogiem i wytrwać w tym stanie. Jest więc człowiekowi niezbędna pomoc Boga w postaci Jego łaski ${ }^{5}$.

Autor Moraliów wyróżnia dwa rodzaje łaski: uprzedzającą, która umożliwia dobre postępowanie człowieka, oraz towarzyszącą, która to postępowanie wspiera. Papież naucza, że uprzedzająca łaska powoduje, iż człowiek może odpowiedzieć pozytywnie na Boże wezwanie do świętości. Ukazuje ona człowiekowi, czego należy chcieć, i daje moc do zrealizowania tego pragnienia. Nie determinuje ona człowieka do pozytywnej odpowiedzi, lecz pozostawia mu w jego wyborze wolną wolę $e^{6}$. Gdy człowiek decyduje się na współpracę z łaską Bożą, wtedy Bóg udziela mu także łaski towarzyszącej, która wspiera jego sprawiedliwe postępowanie ${ }^{7}$.

${ }^{4}$ Por. Gregorius Magnus, Moralia in Iob XXXV, 17, 44; XXXV, 8, 17; VII, 25, 30; VIII, 7, 12; VIII, 8, 14; XIX, 25, 42.

${ }^{5}$ Por. tamże XXVII, 16, 32; X, 35, 67; XIX, 6, 12; IX, 53, 79; zob. G. R. Evans, The Thought of Gregory the Great, Cambridge 1986, s. 69-70; P. Gwiazda, Życie kontemplacyjne wedtug św. Grzegorza Wielkiego, Warszawa 2001, s. 21-23; C. Dagens, Saint Grégoire le Grand. Culture et expérience chrétiennes, Paris 1977, s. 187-191.

${ }^{6}$ Por. Gregorius Magnus, Moralia in Iob XIX, 29, 52; XVI, 25, 30; XIV, 32, 41; XVIII, 40, 63 - zob. S. Rosik, Rola Kościoła jako zbawczej wspólnoty w doktrynie papieża Grzegorza Wielkiego, „Roczniki Teologiczno-Kanoniczne” 24 (1977) 3, s. 35; G. R. Evans, The Thought of Gregory the Great, dz. cyt., s. 69.

${ }^{7}$ Por. Gregorius Magnus, Moralia in Iob XX, 3, 8; XXIII, 27, 53; zob. W. Furman, Wplyw św. Grzegorza na św. Tomasza z Akwinu w doktrynie o darach Ducha Świętego, Lublin 1961, s. 20-21. Grzegorz Wielki inspirował się myślą Augustyna, ale był ostrożny wobec jego nauki o przeznaczeniu, która głosiła, że chociaż wszyscy otrzymują łaskę, to jednak tylko ci, których Bóg wybiera, otrzymują łaskę końcowej wytrwałości. Grzegorz Wielki podkreśla zawsze inicjatywę Boga, ale zwraca uwagę, że także zaangażowanie człowieka jest konieczne do zbawienia; por. Gregorius Magnus, Moralia in Iob XXXIII, 21, 38; XXIII, 6, 13; XXXIII, 21, 40; XVI, 7, 13; XVI, 25, 30; zob. S. Rosik, Rola Kościoła ..., dz. cyt., s. 34-35; B. Studer, 
Łaska Boża, zdaniem biskupa Rzymu, jest nie tylko środkiem umożliwiającym i wspomagającym nabywanie cnót, ale jest przede wszystkim ich bezpośrednim źródłem. Według Grzegorza Wielkiego, wszystkie cnoty są człowiekowi dane przez działanie Ducha Świętego i pochodzą z łaski Bożej jak ze źródła ${ }^{8}$. Należy zaznaczyć, że autor Moraliów zwraca uwagę, iż dzięki łasce Bożej człowiek nabywa cnoty nie od razu, lecz stopniowo'.

\section{Współpraca człowieka z łaską Bożą}

Grzegorz Wielki jest przekonany, że na uzdalniający i wspomagający w nabywaniu cnót dar Bożej łaski człowiek powinien dać pozytywną odpowiedź, podporządkowując łasce swoją wolną wolę. To od wyboru człowieka zależy, czy będzie on trwał w stanie łączności z Bogiem, czy w stanie oddalenia od Niego ${ }^{10}$. Podporządkowanie przez chrześcijanina swojej wolnej woli Bożej łasce powinno wyrazić się w praktykowaniu konkretnych postaw, które umożliwiają człowiekowi duchowe wzrastanie i w tym wzrastaniu utrwalają go ${ }^{11}$.

Niniejsza część artykułu jest poświęcona przedstawieniu zachowań i praktyk, które autor Moraliów uważa za konieczne środki prowadzące do duchowej łączności z Bogiem. Należy podkreślić, że Grzegorz Wielki

Teologia patrystyczna, [w:] Historia Teologii, t. 1: Epoka patrystyczna, red. A. di Bernardino, B. Studer, tłum. M. Gołębiowski, J. Łukaszewska, J. Ryndak, P. Zarębski, Kraków 2003, s. 624; C. Dagens, Saint Grégoire..., dz. cyt., s. 415; H. H. Howorth, Saint Gregory the Great, London 1912, s. 280-287.

${ }^{8}$ Por. Gregorius Magnus, Moralia in Iob XVII, 31, 48; VIII, 29, 48; I, 27, 38; II, 49, 77; zob. G. C. Carluccio, The Seven Steps to spiritual perfection according to st. Gregory the Great, Ottawa 1949, s. 25.

${ }^{9}$ Por. Gregorius Magnus, Moralia in Iob XXII, 19, 45-20, 46; XXII, 20, 51; XXII, 20, 4647; zob. G. R. Evans, The Thought of Gregory the Great, dz. cyt., s. 110; P. Gwiazda, Życie..., dz. cyt., s. 35; L. Nieścior, Implikacje moralne nauki o czasie w „Moraliach” św. Grzegorza Wielkiego, „Teologia Patrystyczna” 2 (2005), s. 77-79. Grzegorz Wielki naucza, że działanie łaski przejawia się w kompunkcji (compunctio), która jest wzruszeniem duszy. Doktryna o kompunkcji jest jednym z najbardziej wartościowych rozwiązań papieża; por. Gregorius Magnus, Moralia in Iob XXVII, 17, 33; V, 28, 50; IX, 53, 80; XVI, 5, 6; tenże, Homiliae in Hiezechielem Prophetam II, 1, 6; I, 5, 2; zob. J. M. Petersen, The „Dialogues” of Gregory the Great in their late antique cultural background, Toronto 1984, s. 160-161; J. Leclercq, Miłość nauki a pragnienie Boga, tłum. M. Borkowska, Kraków 1997, s. 40; C. Dagens, Saint Grégoire..., dz. cyt., s. 406; Carluccio, The seven steps..., dz. cyt., s. 43-48; M. Casey, Spiritual Desire ..., dz. cyt., s. 310-311. Szerzej na temat kompunkcji por. P. Regamey, La 'compunction du coeur' en St. Grégoire le Grand et St. Isidor de Séville, „Vie Spirituelle” 44 (1935), s. 65-84.

${ }^{10}$ Por. Gregorius Magnus, Moralia in Iob XXXIII, 21, 40; XVIII, 40, 63; XIX, 29, 52; XXXIII, 21, 39; XII, 19, 24; zob. C. Dagens, Saint Grégoire..., dz. cyt., s. 415; S. Rosik, Finalizm..., dz. cyt., s. 221.

${ }^{11}$ Por. Gregorius Magnus, Moralia in Iob XXXV, 17, 44; XIX, 30, 53. 
w swoim nauczaniu zwraca się do ludzi już w pewnym stopniu ugruntowanych w wierze chrześcijańskiej ${ }^{12}$. Dlatego środki, które proponuje, odpowiadają ludziom, którzy posiadają mniejsze lub większe przygotowanie duchowe, a nie dopiero poznającym chrześcijaństwo.

\section{Pragnienie Boga}

Według Grzegorza Wielkiego podstawowym warunkiem każdego duchowego wzrostu jest pragnienie Boga ${ }^{13}$. Człowiek, chociaż ma zakorzenione to pragnienie w naturze, musi jednak w swej świadomości, przy pomocy łaski Bożej, pobudzić je i uaktualnić14 ${ }^{14}$ Samo duchowe pragnienie jest formą miłości Boga w tym życiu ${ }^{15}$. Miłość ta jest równocześnie energią, która daje moc duchowemu pragnieniu i dzięki niej dokonuje się wszelki duchowy wzrost ${ }^{16}$.

Według autora Moraliów duchowe pragnienie jest już w pewnym stopniu trwaniem w stanie łączności z Bogiem ${ }^{17}$. Człowiek może rozwijać je w nieskończoność. W miarę jak ono wzrasta, nagradzane jest coraz większym stopniem duchowej doskonałości. Pragnienie to jednak podobnie jak nie może powstać bez pobudzenia go, tak też nie może trwać i rozwijać się bez podtrzymywania przez konkretne formy dobrego postępowania, które zarazem są wyrazem tego pragnienia ${ }^{18}$. Obecnie przechodzimy do omówienia zachowań i praktyk, które są środkami żywienia duchowego pragnienia.

${ }^{12}$ Por. C. Dagens, Saint Grégoire..., dz. cyt., s. 262.

${ }^{13}$ Por. P. Catry, Désir et amour de Dieu chez Saint Grégoire le Grand, „,Recherches Augustiniennes" 10 (1975), s. 285-286; P. Gwiazda, Życie..., dz. cyt., s. 67. Temat pragnienia Boga jest przewodni w nauczaniu Grzegorza Wielkiego. Dlatego niektórzy współcześni badacze nazywają go „mistrzem pragnienia”; por. M. Casey, Spiritual Desire..., dz. cyt., s. 299; J. Leclercq, Miłość nauki..., dz. cyt., s. 41.

${ }^{14}$ Por. M. Casey, Spiritual Desire..., dz. cyt., s. 312.

${ }^{15}$ Por. Gregorius Magnus, Homiliae in Evangelia II, 29, 11; II, 30, 10; zob. M. Casey, Spiritual Desire..., dz. cyt., s. 313; J. Leclercq, Miłość nauki..., dz. cyt., s. 42; J. Morson, Seeking God by desire, „Cistercian Studies” 2 (1967), s. 175-185.

${ }^{16}$ Por. Gregorius Magnus, Moralia in Iob VI, 37, 58; tenże, Homiliae in Evangelia II, 27, 4; zob. M. Casey, Spiritual Desire..., dz. cyt., s. 306-308. 313; P. Gwiazda, Życie..., dz. cyt., s. 167-168; S. Sojka, Ideat życia kapłańskiego w świetle pism świętego Grzegorza Wielkiego, Lublin 2003, s. 89-97.

${ }^{17}$ Por. Gregorius Magnus, Homiliae in Evangelia II, 38, 4; II, 30, 1; zob. M. Casey, Spiritual Desire..., dz. cyt., s. 302. 313; P. Catry, L'Amour du prochain chez Saint Grégoire le Grand, „Studia Monastica” 20 (1978) 2, s. 287-344.

${ }^{18}$ Por. Gregorius Magnus, Homiliae in Evangelia II, 36, 1; I, 2, 1; zob. M. Casey, Spiritual Desire..., dz. cyt., s. 303. 312; J. Leclercq, Miłość nauki..., dz. cyt., s. 42. 


\section{UMYSŁOWE ODERWANIE SIĘ OD ZIEMSKICH PRZYWIĄZAŃ}

Według Grzegorza Wielkiego, koniecznym warunkiem rozwoju duchowego pragnienia jest przede wszystkim postawa umysłowego wyrzeczenia się przywiązania do spraw tego świata. Przywiązanie to jest niczym innym, jak umiłowaniem dóbr ziemskich. Nie można pogodzić miłości do dóbr ziemskich i duchowych, ponieważ obydwa rodzaje miłości wzajemnie się zwalczają. Papież przypomina ewangeliczną przypowieść o siewcy (Mt 13, 22; Łk 8, 7-8; Mk 4, 7), która ukazuje, że troski związane z uczuciowym przywiązaniem się do tego świata tłumią słowo Boże i pozbawiają je owocu. W przekonaniu autora Moraliów tylko spokojny umysł niezajęty ziemskimi myślami może złączyć się z Bogiem ${ }^{19}$.

Człowiek dopiero po duchowym oddaleniu się od świata doświadcza łączności z Bogiem. Wyrażając tę prawdę papież powołuje się na przykład starotestamentalnego Jakuba (Rdz 28, 11), który zamierzając odpocząć w drodze, pod głowę podłożył kamień i usnął. We śnie widział drabinę, która łączyła niebo z ziemią, Boga oraz wstępujących i zstępujących aniołów. Autor Moraliów wyjaśnia, że odpoczynek w drodze oznacza duchowe wyciszenie się (quiescere) na skutek wewnętrznego doświadczenia przemijalności tego życia i oddalenie się od miłości do tego, co wiąże człowieka z ziemskim światem. Kamień, który Jakub podłożył pod głowę, jest symbolem umysłowego przylgnięcia do Chrystusa. Oglądanie aniołów oznacza kontemplowanie mieszkańców niebiańskiej ojczyzny. W ten sposób Grzegorz Wielki ukazuje, że warunkiem wzniesienia się człowieka do duchowej łączności z Bogiem, która swoją pełnię w życiu ziemskim osiąga w kontemplacji, jest oderwanie się od przywiązań do spraw tego świata i ukierunkowanie umysłu ku Bogu ${ }^{20}$.

${ }^{19}$ Por. Gregorius Magnus, Moralia in Iob XVIII, 9, 16; V, 11, 19; XVIII, 43, 68; XXX, 27, 80; XVIII, 43, 68; XVIII, 54, 89; XXVII, 13, 25; I, 5, 6; XX, 15, 39-40; XXXIII, 37, 63; V, 31, 54; tenże, Homiliae in Evangelia I, 5, 2; I, 17, 14; I, 19, 5; zob. M. Casey, Spiritual Desire ..., dz. cyt., s. 299. 301; J. Leclercq, Miłość nauki..., dz. cyt., s. 39. 42; P. Gwiazda, Życie ..., dz. cyt., s. 45. 50-52; S. Rosik, Finalizm..., dz. cyt., s. 88-90; A. De Vogüé, The Views of St. Gregory the Great on the Religious Life in his Commentary on the Book of Kings (I), „Cistercian Studies” 17 (1982) 1, s. 47-48; tenże, The Views... (II), „Cistercian Studies” 17 (1982) 3, s. 218-220; P. Catry, Amour du monde et amour de Dieu chez Saint Grégoire le Grand, „Studia Monastica” 15 (1973) 2, s. 265-275; S. Sojka, Ideat życia ..., dz. cyt., s. 215-218; P. Daubercies, La théologie de la conditio charnelle chez les Maîtres du haut moyen âge, „Recherche de Théologie ancienne et médiévale" 30 (1963), s. 32-52.

${ }^{20}$ Por. Gregorius Magnus, Moralia in Iob V, 31, 54-55; zob. tamże IV, 30, 58; XVIII, 9 , 16; I, 5, 7; I, 6, 8; VIII, 26, 45; por. P. Gwiazda, Życie ..., dz. cyt., s. 57. 166-173; G. A. Zinn, Sound, silence and word in the spirituality of Gregory the Great, [w:] Grégoire le Grand. Colloques internationaux du Centre National de la Recherche Scientifique, red. J. Fontaine, R. Gillet, S. Pellistrandi, Paris 1986, s. 369-370; S. Sojka, Ideat życia..., dz. cyt., s. 216. 
Według autora Moraliów, duchowe zdystansowanie się od świata i umysłowe przylgnięcie do Boga oznacza także absolutne wyrzeczenie się wszelkich niegodziwości, grzechu ${ }^{21}$, a nawet powstrzymanie się od zbędnych rzeczy dozwolonych ${ }^{22}$ i pokorne przyjęcie cierpienia ${ }^{23}$. W praktykowaniu takiej postawy należy jednak zachować właściwą proporcję ${ }^{24}$.

\section{SŁUCHANIE SŁOWA BoŻEGO}

Grzegorz Wielki naucza, że człowiek, który oczyszcza swoje pragnienia od ziemskich przywiązań i dąży do łączności z Bogiem, powinien przede wszystkim czerpać siły z mądrości słowa Bożego zachowanego w Piśmie Świętym, które jest szczególnym źródłem łaski. Ukazuje ono bowiem prawdę i uzdalnia serce czytelnika do umiłowania rzeczywistości niebiańskiej. Im bardziej człowiek zgłębia bogactwo treści Pisma Świętego, tym bardziej doskonali się

${ }^{21}$ Por. Gregorius Magnus, Homiliae in Evangelia I, 2, 1; zob. M. Casey, Spiritual Desire..., dz. cyt., s. 303 .

${ }^{22}$ Por. Gregorius Magnus, Moralia in Iob V, 11, 17; zob. S. Sojka, Ideat życia ..., dz. cyt., s. 107; tenże, Asceza w świetle pism św. Grzegorza Wielkiego, „Vox Patrum” 7 (1987) t. 12-13, 337-344; J. Leclercq, Miłość nauki..., dz. cyt., s. 39.

${ }^{23}$ Por. Gregorius Magnus, Homiliae in Hiezechielem Prophetam II, 4, 2; tenże, Homiliae in Evangelia I, 3, 4; zob. Nieścior, Implikacje moralne..., dz. cyt., s. 84-85; S. Sojka, Ideat życia ..., dz. cyt., s. 109-112; P. Gwiazda, Życie..., dz. cyt., s. 51. Zgodnie z nauczaniem Grzegorza Wielkiego duchowe zdystansowanie się od świata i umysłowe przylgnięcie do Boga, które wymaga absolutnego wyrzeczenia się wszelkich niegodziwości, grzechu, a nawet powstrzymania się od zbędnych rzeczy dozwolonych, wymaga od chrześcijanina ciężkiego wysiłku, który papież nazywa duchowym męczeństwem (martyrium [...] in mente). Polega ono na zniszczeniu w swojej duszy, niejako przez duchowy miecz, cielesnych pragnień, na przezwyciężeniu siebie ze względu na miłość do Chrystusa; por. Gregorius Magnus, Homiliae in Evangelia II, 35, 7; I, 3, 4; I, 5, 2; I, 17, 14; I, 19, 5; I, 2, 1; zob. tenże, Moralia in Iob V, 11, 17; XIV, 35, 42; por. A. C. Rush, Spiritual Martyrdom in St. Gregory the Great, „Theological Studies” 23 (1962) 4, s. 576-579; A. de Vogüé,,,Martyrium in occulto”. Le Martyre du temps de paix chez Grégoire le Grand, Isidore de Seville et Valerius du Bierzo, [w:] Fructus Centessimus, red. A. A. Bastiaensen, A. Hilhorst, C. H. Kneepkens, Steenbrugis 1989, s. 128-132; tenże, The Views... (I), s. 47-48; tenże, The Views... (II), s. 218-220; M. Casey, Spiritual Desire..., dz. cyt., s. 299. 301. 303; R. A. Markus, Grzegorz Wielki, tłum. P. Nehring, Warszawa 2003, s. 78-80; P. Gwiazda, Życie..., dz. cyt., s. 114-115. 70. 45. 50-52; J. Leclercq, Miłość nauki..., dz. cyt., s. 39. 41-42; Nieścior, Implikacje moralne ..., dz. cyt., s. 84-85; M. Porcel, La doctrina monastica de S. Gregorio Magno y la „Regula Monachorum”, Madrid 1951, s. 85-89; S. Sojka, Ideał życia..., dz. cyt., s. 107-112. 207; tenże, Asceza w świetle pism św. Grzegorza Wielkiego, „Vox Patrum” 7 (1987) t. 12-13, 340-342.

${ }^{24}$ Por. Gregorius Magnus, Moralia in Iob XXXI, 38, 77; tenże, Homiliae in Hiezechielem Prophetam II, 7, 19; zob. M. Porcel, La doctrina ..., dz. cyt., s. 89-96; A. De Vogüé, The Views... (I), s. 56. 62; tenże, The Views... (II), s. 227-228; S. Sojka, Ideat życia ..., dz. cyt., s. 107-109; tenże, Asceza ..., dz. cyt., s. 339-340. 
w miłości do Boga i rozwija się duchowo ${ }^{25}$. Grzegorz Wielki zwraca uwagę, że podobnie jak duchowy postęp człowieka zależy od postępu w rozumieniu słów Biblii, tak też odwrotnie, postęp w rozumieniu Pisma Świętego zależy od postępu w cnocie. Prawdę tę wyraża w sformułowaniu, że „Boskie wypowiedzi wzrastają wraz z osobami, które je czytają" (divina eloquia cum legente crescunt), co oznacza, że głębia prawdy zawartej w słowie Bożym odkrywa się coraz bardziej dla osób wzrastających w cnocie i duchowym postępie. Wzrost ten może pogłębiać się w nieskończonośćc ${ }^{26}$.

\section{NAŚLADOWANIE LUDZI SPRAWIEDLIWYCH}

Biskup Rzymu jest przekonany, że często bardziej pobudza człowieka do praktykowania cnoty przykład sprawiedliwej osoby niż głoszenie słowa Bożego ${ }^{27}$. Dlatego obok Pisma Świętego Grzegorz Wielki podkreśla znaczenie wzorowania się na życiu ludzi sprawiedliwych, którzy swoim przykładem zachęcają do przyjmowania i wypełniania Bożego słowa. Przykładów tych należy poszukiwać przede wszystkim w życiu biblijnych Ojców ${ }^{28}$. Papież zwraca uwagę, że Pismo Święte nie tylko ukazuje cnoty postaci biblijnych, ale również ich duchowe upadki, aby człowiek w sprawiedliwości innych widział to, co powinien naśladować, a w upadkach dostrzegał to, czego powinien się wystrzegać ${ }^{29}$. W swojej prezentacji biblijnych postaci ludzi sprawiedliwych Grzegorz Wielki dochodzi do najważniejszej z nich - Syna Bożego Jezusa Chrystusa, który nie tylko odkupił człowieka, lecz przemienił go, ukazując mu wzór postępowania ${ }^{30}$.

${ }^{25}$ Por. Gregorius Magnus, Moralia in Iob XX, 1, 1; XXIX, 32, 76; XV, 13, 16; XXVII, 12 , 22; zob. C. Dagens, Saint Grégoire..., dz. cyt., 268; P. Gwiazda, Życie ..., dz. cyt., s. 80-85; M. Porcel, La doctrina ..., dz. cyt., s. 149-154; A. Tomkiel, Ojcowie Kościoła ucza nas modlitwy, thum. Z. Zwolska, Warszawa 1995, s. 138-143.

${ }^{26}$ Por. Gregorius Magnus, Homiliae in Hiezechielem Prophetam I, 7, 8; zob. tenże, Moralia in Iob XX, 1, 1; por. P. C. Bori, Circolarità e sviluppo nell'interpretazione spirituale: „Divina eloquia cum legente crescunt” (Gregorio M., In Hiez. I, VII, 8), „Annali di storia dell' esegesi” 2 (1985), s. 263-274; B. Calami, S. Gregorio, maestro di formazione spiritualis, „Seminarium” 10 (1969) 2, s. 261-263; P. Gwiazda, Życie ..., dz. cyt., s. 82; Tomkiel, Ojcowie ..., dz. cyt., s. 139.

${ }^{27}$ Por. Gregorius Magnus, Homiliae in Evangelia II, 38, 15; tenże, Moralia in Iob II, 39, 10; zob. G. R. Evans, The Thought of Gregory the Great, dz. cyt., s. 96-97.

${ }^{28}$ Por. Gregorius Magnus, Moralia in Iob XXIV, 8, 15-21; XXXI, 48, 97; XVI, 23, 28; XXVII, 10, 16; XXVII, 10, 16-11, 20; XXVII, 10, 16-11, 20; V, 6, 10; XXIII, 19, 34; XXVII, 10, 18; zob. A. de Vogüé, Wstęp, tłum. D. Stanicka-Apostoł, [w:] Grzegorz Wielki. Dialogi, thum. E. Czerny, A. Świderkówna, Kraków 2000, s. 23-60.

${ }^{29}$ Por. Gregorius Magnus, Moralia in Iob II, $1,1$.

${ }^{30}$ Por. tamże XV, 45, 51; XXX, 24, 69; XVII, 7, 9; XXV, 12, 30; III, 16, 30; XXX, 21, 66; II, 37, 60; zob. P. Gwiazda, Życie..., dz. cyt., s. 38-41; G. R. Evans, The Thought of Gregory the Great, dz. cyt., s. 66-67; S. Rosik, Finalizm ..., dz. cyt., s. 120-129; S. Sojka, Ideat zycia..., dz. cyt., s. 64-87. 
Autor Moraliów zachęca do wpatrywania się również w życie sobie współczesnych ludzi. Zdaniem papieża, każdy człowiek posiada taką cnotę, której brakuje innemu. W ten sposób przez niezwykłe Boże zarządzanie dzieje się tak, że jeden drugiemu ukazuje się jako lepszy. To powoduje, że każdy może doskonalić się w pokorze, ponieważ przez cnoty, których nie posiada, powinien uważać siebie za niższego od posiadającego je ${ }^{31}$.

\section{ModLITwa}

Zgodnie z nauczaniem biskupa Rzymu, treści duchowego życia, czerpane z Pisma Świętego i z przykładów sprawiedliwych ludzi, powinny być duchowo przeżywane. Potężnym środkiem w tym zakresie jest modlitwa, przez którą człowiek przyswaja słowo Boże i odnawia nadprzyrodzone życie, ubogacając się duchowymi dobrami ${ }^{32}$.

Ważnym elementem modlitwy o dobra duchowe jest szczere pragnienie tych dóbr przez człowieka, które jest potężniejsze niż słowa. Papież pisze, że jeżeli człowiek ustami prosi o życie wieczne uobecniane w cnotach, a nie pragnie tego w sercu, wołając milczy. Jeżeli natomiast pragnie w sercu, to woła, nawet gdy usta milczą. Dlatego nasz autor jest przekonany, że Bóg udziela cnoty, która z pragnienia jest pożądana ${ }^{33}$.

\section{KORZYSTANIE Z ŁASKI SAKRAMENTÓW}

Grzegorz Wielki pisze, że duchowe wysiłki człowieka nieustannie powinny umacniać się przez korzystanie z łaski sakramentów. Człowiek, aby ubogacić się cnotami, musi czerpać ze źródła łaski we wspólnocie jedynego Kościoła ${ }^{34}$.

${ }^{31}$ Por. Gregorius Magnus, Moralia in Iob XXIV, 8, 19. Zgodnie z nauczaniem Grzegorza Wielkiego, podobnie jak Pismo Święte i życie ludzi sprawiedliwych, tak też cała przyroda jest znakiem, przez który objawia się Bóg. Przez rozważanie nad widzialnym światem można wznieść się do świata niewidzialnego; por. Gregorius Magnus, Moralia in Iob XI, 4, 6; VI, 15, 18-19; XXVI, 12, 18; XXX, 5, 20; zob. Markus, Grzegorz Wielki, s. 65-66; M. Frickel, Deus totus ubique simul. Untersuchungen zur allgemeinen Gottgegenwart im Rahmen der Gotteslehre Gregors des Großen, Freiburg 1956, s. 10-21; Zinn, Sound..., dz. cyt., s. 368-369; R. A. Markus, The Jew as a hermeneutic decise: The inner life of a Gregorian topos, [w:] Gregory the Great. A symposium, red. J. C. Cavadini, London 2001, s. 9-10; G. R. Evans, The Thought of Gregory the Great, dz. cyt., s. 38-40. 46-47. 102-103.

${ }^{32}$ Por. Gregorius Magnus, Moralia in Iob XV, 47, 53; zob. Tomkiel, Ojcowie..., dz. cyt., s. 138. 144-148; C. Dagens, Saint Grégoire ..., dz. cyt., s. 268; P. Gwiazda, Życie ..., dz. cyt., s. 55; S. Sojka, Ideał życia..., dz. cyt., s. 136; J. Leclercq, Miłość nauki J. Leclercq, Miłość nauki..., dz. cyt., s. 39; M. Porcel, La doctrina ..., dz. cyt., s. 96-97. 135-137.

${ }^{33}$ Por. Gregorius Magnus, Moralia in Iob XXII, 17, 43; XVI, 22, 27. Należy zaznaczyć, że Grzegorz Wielki oprócz modlitwy indywidualnej podkreślał doniosłe znaczenie modlitwy liturgicznej; por. H. Aslworth, The liturgical prayers of St. Gregory the Great, „Traditio” 15 (1959), s. 107-161.

${ }^{34}$ Por. Gregorius Magnus, Moralia in Iob III, 22, 44; zob. P. Gwiazda, Życie ..., dz. cyt., s. 30. 
Momentem wejścia do Kościoła jest sakrament chrztu ${ }^{35}$. Biskup Rzymu zwraca uwagę, że chrześcijanin oczyszczony we chrzcie z grzechu pierworodnego i wszczepiony w nadprzyrodzone życie nadal jednak jest podatny na grzech. Jeżeli popełnia go, zrywa łączność z Chrystusem. W tym przypadku Bóg daje człowiekowi szansę powrotu do łączności z Nim w łasce sakramentu pokuty, która odradza człowieka do nadprzyrodzonego życia i odnawia zerwaną więź z Bogiem ${ }^{36}$. Grzegorz Wielki podkreśla także znaczenie łaski sakramentu Eucharystii, który chroni i pogłębia duchowe życie chrześcijanina. W niej uobecnia się misterium śmierci Chrystusa; jako szczególna ofiara uwalnia ona duszę od wiecznej zagłady i uzdalnia ją do zbawienia ${ }^{37}$. Według autora Moraliów wszelkie uświęcenie człowieka przez sakramentalną łaskę dokonuje się za pośrednictwem Chrystusa, który jest Głową Kościoła iźródłem nadprzyrodzonego życia dla jego członków. On posiada w sposób trwały wszelkie łaski Ducha Świętego i nimi napełnia człowieka. Dlatego jest źródłem odkupienia, uświęcenia i duchowej doskonałości człowieka ${ }^{38}$.

\section{PRZESTRZEGANIE PRZYKAZAŃ}

W przekonaniu Grzegorza Wielkiego wszelka cnota i dobre postępowanie prawdziwie realizują się wtedy, gdy w życiu człowieka korzystanie z łaski sakramentów jest połączone z zachowywaniem przykazań, w których streszcza się Boża wola ${ }^{39}$. W nawiązaniu do Ewangelii (J 15, 14-15) autor Moraliów przypomina, że ten, kto usiłuje zachować przykazania, jest Bożym przyjacielem. Odwołując się do etymologii słowa „przyjaciel” (amicus), Grzegorz Wielki wyprowadza wniosek, że Boży przyjaciel jest stróżem duszy

${ }^{35}$ Por. Gregorius Magnus, Moralia in Iob XV, 51, 57; IV, 3, Praefatio; XVIII, 53, 87; zob. S. Rosik, Rola Kościoła..., dz. cyt., s. 31-32.

${ }^{36}$ Por. Gregorius Magnus, Homiliae in Evangelia II, 25, 9; tenże, Moralia in Iob XII, 6, 9; IX, 55, 84; IV, 19, 36; XX, 22, 49; XII, 15, 19; XXVII, 19, 39-24, 45; XXVII, 16, 32; IX, 36, 56; III, 31, 61; II, 51, 81; XVI, 20, 25; IX, 58, 88; XIX, 20, 31; IV, 15, 27; II, 51, 81; X, 15 , 27; IX, 62, 93; V, 22, 44; tenże, Homiliae in Hiezechielem Prophetam II, 10, 7; II, 4, 17; II, 8, 19; zob. S. Rosik, Rola Kościoła..., dz. cyt., s. 32. 36; G. R. Evans, The Thought of Gregory the Great, dz. cyt., s. 37. Obszerniej na temat pokuty w nauczaniu Grzegorza Wielkiego por. J. Tixeront, La doctrine pénitentielle de saint Grégoire le Grand, „Bulletin d'ancienne literature et d'archéologie chrétiennes" (1912) 4, s. 241-258.

${ }^{37}$ Por. Gregorius Magnus, Moralia in Iob XXII, 13, 26; XIII, 23, 26; tenże, Homiliae in Evangelia II, 22, 7-8; II, 37, 7; tenże, Dialogorum libri IV, 58; II, 37; zob. S. Rosik, Rola Kościoła ..., dz. cyt., s. 33; P. Gwiazda, Życie..., dz. cyt., s. 87-89; A. de Vogüé, Eucharistie et vie monastique, „Collectanea Cisterciensia” 48 (1986), s. 120-130; tenże, Wstęp, [w:] Grzegorz Wielki. Dialogi, s. 22-23; S. Sojka, Ideat życia ..., dz. cyt., s. 142-145.

${ }^{38}$ Por. Gregorius Magnus, Moralia in Iob Praefatio, 6, 14; XXIX, 31, 74; XXXI, 45, 87; zob. Carluccio, The Seven Steps..., dz. cyt., s. 33-36.

${ }^{39}$ Por. Gregorius Magnus, Moralia in Iob XXVII, 15, 28; tenże, Homiliae in Evangelia II, $24,4$. 
(amicus $=$ animae + custos). Zachowywanie przykazań jest więc strzeżeniem duszy, czyli zachowywaniem duchowego życia człowieka ${ }^{40}$. Nadzieja życia wiecznego sprawia, że przykazania stają się lekkie do wypełnienia ${ }^{41}$.

\section{DOBRE UCZYNKI}

Grzegorz Wielki naucza, że miłość do Boga powinna być zawsze aktywna. Nawet przyjęcie sakramentów jest nieskuteczne, jeżeli nie wywiera wpływu na zewnętrzną stronę ludzkiego życia. Bez dobrych uczynków miłość do Boga byłaby niekompletna ${ }^{42}$. Przez pełnienie dobrych uczynków człowiek oczyszcza się z grzechów, nabywa cnoty i ożywia ducha ${ }^{43}$. Autor Moraliów podkreśla, że dobre uczynki mają wartość tylko wtedy, gdy wypływają z pragnienia Boga ${ }^{44}$. Śledząc myśl Papieża możemy zauważyć, że tak mocno akcentuje on wartość dobrych uczynków w nabywaniu cnót, iż zdaje się nawet same dobre uczynki uważać za cnotę ${ }^{45}$.

OLEKSANDR KASHCHUK STD

\section{Słowa kluczowe}

Grzegorz Wielki, łaska Boża, wolna wola, cnota, duchowa doskonałość, Bóg, człowiek

\section{Summary}

\section{The way of Christian perfection according to the teaching of Gregory the Great}

The main purpose of the article is to look at the doctrine of Gregory the Great and explore his teaching on the means, through which a Christian can advance spiritually, i.e. achieve a spiritual unity with God. According to the teaching of Gregory the Great, a human being in his/her nature constantly pursues God. To realize human natural longing, the human needs the assistance of God's grace. The human should consent to the cooperation with God's grace. First of all, one should discover and wake up in one's self the longing for God, which is the force d'etre of every spiritual development. This longing for God is a state

${ }^{40}$ Por. tenże, Moralia in Iob XXVII, 15, 28; zob. tamże XXVII, 37, 61; XXVII, 15, 30; XXX, 17, 56; IV, 31, 61; XII, 6, 9.

${ }^{41}$ Por. tamże XXVI, 31, 57; I, 16, 24.

${ }^{42}$ Por. tamże II, 30, 2; XXXIII, 6, 12; tenże, Homiliae in Evangelia II, 22, 8; I, 9, 6; II, 38, 11; II, 39, 9; zob. M. Casey, Spiritual Desire ..., dz. cyt., s. 312-313; C. Dagens, Saint Grégoire..., dz. cyt., s. 268; S. Rosik, Rola Kościoła ..., dz. cyt., s. 33; P. Gwiazda, Życie..., dz. cyt., s. 54.

${ }^{43}$ Por. Gregorius Magnus, Moralia in Iob XVI, 51, 64; II, 51, 81; XXXII, 2, 2; XVI, 51, 64; II, 51, 81; XIX, 30, 53; VI, 26, 43; XIX, 16, 25; I, 4, 5; zob. M. Casey, Spiritual Desire..., dz. cyt., s. 312 .

${ }^{44}$ Por. Gregorius Magnus, Moralia in Iob XIV, 20, 24; tenże, Homiliae in Evangelia II, 24, 4; zob. M. Casey, Spiritual Desire..., dz. cyt., s. 314.

${ }^{45}$ Por. Gregorius Magnus, Moralia in Iob VII, 24, 29; XXXII, 2, 2. 
of the introductory unity with God. To improve and solidify this longing human's should purify it from the earthly devotion, then spiritually improve one's self in the reading of the Holy Scripture, model one's self after the life of just people, pray, make use of sacramental grace, observe the commandments of God, and do good deeds.

\section{Keywords}

Gregory the Great, God's grace, free will, virtue, spiritual perfection, God, human being 
